\title{
Effect of Work Environment and Motivation of Employee Performance
}

\author{
Daspar $^{1}$, Miftakul Huda ${ }^{2}$ \\ Pelita Bangsa University \\ daspar@pelitabangsa.ac.id ${ }^{1}$, miftakulhuda@pelitabangsa.ac.id ${ }^{2}$
}

\begin{abstract}
This study aims to analyze the effect of work environment and motivation on the performance of PT. XYZ. Research data from questionnaire and secondary data. The sampling method used was probability sampling. From a population of 70 people, 70 people become the sample. The method of analysis used in this study is multiple linear regression. The result showed that work environment and motivation simultaneously are having significant influence to the performance of PT. XYZ. Partially work environment has positive significant effect on the performance, while motivation has a significant negative effect.
\end{abstract}

Keywords: Work Environment, Motivation, Performance.

\section{Introduction}

Human resources are an important role for the organization or company, because humans are assets that need to be considered by the company. Therefore, humans as living assets must get serious attention and be managed properly. This discusses that the human resources needed by the company contribute optimally to the organization or company in an effort to achieve organizational goals. In managing human resources, management needs to be able to manage system resources, planned and efficient.

According to Kasmir (2016: 6), that human resource management is a process of human management, through planning, recruitment, selection, training, development, compensation, training, safety and health as well as work safety shifting to find companies and improve the welfare of stakeholders interests.

Performance is the result of quality and satisfying work requested by an employee in a task that is in accordance with the responsibilities given (Mangkunegara, 2013). Employee performance can be implemented well if it is in accordance with the desired goals or in accordance with the needs of the company, but it is necessary to improve the ability of employees needed (Daniel Surjosuseno, 2015).

Performance of PT. XYZ can be seen from the support of employees in the production department who support each other in each section, including the welding section (welding). In this section some components are welding before being sent to the next process, before finally being assembled into a motorcycle unit. These components are called fuel tanks as a place for motorcycle fuel and body frame as approved by the motorcycle unit.

The welding productivity of PT. XYZ in 2015 is as follows: 
Table 1. Welding Section Production Data Of PT. XYZ 2015

\begin{tabular}{rccccc}
\hline No & Month & $\begin{array}{c}\text { Planning } \\
\text { Deviation (Unit) }\end{array}$ & $\begin{array}{c}\text { Achievement Rate } \\
\text { ( Unit) }\end{array}$ & \multicolumn{2}{c}{$\begin{array}{c}\text { Actual } \\
\text { (In Percentage) }\end{array}$} \\
\hline 1 & Januari & 168.575 & 167.825 & -750 & 99.6 \\
2 & Febniari & 180.100 & 178.150 & -1.950 & 98,9 \\
3 & Maret & 189.234 & 189.334 & 100 & 100.05 \\
4 & April & 182.000 & 182.000 & 0 & 100 \\
5 & Mei & 150.002 & 150.102 & 100 & 100.06 \\
6 & Juni & 209.000 & 207.270 & -1.730 & 99 \\
7 & Juli & 143.266 & 143.266 & 0 & 100 \\
8 & Agustus & 235.600 & 234.715 & -885 & 99,6 \\
9 & September & 217.800 & 217.800 & 0 & 100 \\
i0 & Okiober & 217.747 & 217.847 & 100 & 100.04 \\
11 & November & 200.950 & 200.950 & 0 & 100 \\
12 & Desember & 167.950 & 167.750 & -200 & 99.9 \\
\hline & & Average & & -435 & 99.8 \\
\hline
\end{tabular}

Source : Production Departement Of PT. XYZ 2015

Based on the data in table 1, it is known that productivity in January, February, June, August, and December did not reach the target according to production planning, with deficits (minus) each of -750 units, $-1,950$ units, $-1,730$ units, -885 units, and -200 units. While in March, May and October, productivity experienced a surplus of 100 units each.

This research will be tested on factors that affect employee productivity. To get an initial picture of the factors that affect employee productivity, the initial pre-research was carried out by researchers by giving surveys to 30 (thirty) employees of PT. XYZ in the Welding Section which is the object of this research. The following are some of the variables that affect employee productivity based on 2017 pre-research results.

Table 2. Factors that affect the Performance of Welding Section Employees of PT. XYZ

\begin{tabular}{llcc}
\hline No & Problem Indicators in PT. XYZ & Total (Person) & Percentage (\%) \\
\hline 1 Work Environment & 12 & 40 \\
2 & Motivation & 7 & 23.33 \\
3 & Work Discipline & 6 & 20 \\
4 & Leadership Style & 3 & 10 \\
5 & Career Development & 2 & 6.67 \\
\hline \multicolumn{2}{r}{ Total } & 30 & 100
\end{tabular}

Source: Result Pra-Research (2017)

Based on preliminary preliminary reeults it is known that the factors that predominantly affect employee performance are the Work Environment and Motivation. These results become a race for researchers to ten the factors that influence employee 
performance significantly. Baaed on the pre-research result shown, then in this ease the writer needs to do deeper research to be able to prove whether thye is an infiuence of the 2 (two) factors on employee pcrfymancc at PT. XYZ.

\section{Literature Review}

\subsection{The Performance}

Performance ie essentially the result of one's work in carrying out their work. According to Ivancevich (2011: 251), "perform e is a set of employee work-related behaviors designed to accomplish organizational goals". Performance the expected result of a person's behavior in carrying out a job. Performance or performance is the re8ult or output of a process (Nurlaila, 2010: 71). According to the behavioral approach in management, performance in the quantity or quality of something produces provided by someone who do the work (Luthane, 2011: 165). Performance is a work performance, which is a comparison between work results and established standards (Dossier, 2010: 41). The concept of performance according to Quick and Nelson (2012: 184), "defining performance is a prerequisite to measuring and evaluating performance on the job". Defining performance as a prerequisite for measuring and evaluating performance at work. In th is ease performance must be clearly defined and understood by employees in the hope that they can do their best at work. Sedarmayanti (2011: 51), also states that performance inch several aspects, namely:

a) Quality of work (quality of work);

b) Quantity of work (quantity of work);

c) Promptness (speed);

d) Spirit of work, cooperation and presence (work spirit, <xroation and presence);

e) Effectiveness and efficiency (effective and efficient);

These five aspects can be used as a measurement in conducting a study of a person's performance level. Besides that, it is also said that in order to make measurements of performance it is determined: "performance = ability x motivation". From this statement, it is clear that to get a picture of one's performance, special assessments of abilities and motive are needed. Based on some of the above understanding, the authors draw the conclusion that performance is the result of work produced by the ability of individuals or groups that are based on the skills, experience, sincerity and time to the maximum. In addition, the authors interpreted that performance as a record of the success of a job that has been achieved by a person through employee performance appraisal carried out by the organization during a certain period and the performance is a qualitative and quantitative results

\subsection{Work Environment}

Some experts define the work environment among others as follows: According to (Nitisemito in Nuraini 2013 : 97) work environment is everything that is around the employee and can affect the carrying out of the task assigned to him for example with the presence of air conditioner (AC), adequate lighting and so on. According to Sunyoto (2012: 43) defines, "The work environment is a very important component in the employee carrying out work activities." The work environment is the overall work facilities and infrastructure that are around employees who are doing work 
that can affect the implementation of the work itself (Gouzaly Saydam, 2005: 226).

\subsection{Physical Work Environment}

The physical work environment is physical forms that are around the workplace that can affect employees directly or indirectly. The physical work environment can be divided into 2 (two) categories, namely: 1) An environment that is directly related to employees. Such as: work centers, chairs, tables and so on; 2) An intermediate or general environment can also be called a work environment that affects the condition, for example: temperature, humidity, air circulation, lighting, noise, mechanical vibrations, unpleasant odors, colors, and others.

To be able to minimize the influence of the physical environment on employees, first step is to study humans, both about their physical and behavioral and physical aspects, and then use $\mathrm{m}$ as a basis for thinking about the appropriate physical environment.

\subsection{Non-Physical Work Environment}

Non-physical work environment is all conditions that occur relating to work relationships, both relationships with superiors and fellow co-workers, or with subordinates This non- physical environment is also a group of work environments that cannot be ignored.

\subsection{Motivation}

The term motivation (motivation) comes from the Latin language, namely movere, which means "to move" (to move). Motivation influences the type of adjustment made by employees in an organization. As for the various formulations for the term motivation, as expressed by Mitchell ( Winardi, 2005: 2), Motivation is a matter that examines how to direct the potential power of subordinates to want to work productively so as to achieve and realize the goals set motivation consists of two words, namely motivation and work.

Meanwhile according to Malayu S.P. Hasibuan (2009: 95): Motivation comes from the basic motive, which has the meaning of a stimulant, desire and willpower to work one's will. Motivation is the giving of a driving force that creates the excitement of someone's work so that they want to cooperate effectively and integrated with all their efforts to achieve satisfaction.

According to Sondang Siagian (2008: 287), motivation is the drive to do everything possible in carrying out their duties in order to achieve success and organizational goals, so that the personal interests of employees will also be maintained as well. Meanwhile, according to Rivai (2009: 455), motivation is a series of attitudes and values that influence individuals to achieve specific things in accordance with individual goals. That attitude and value is an invisible that gives strength to encourage individuals to behave in achieving goals. The drive consists of the two components, namely the behavioral direction (work to achieve the goal), and the strength of the behavior (how strong the individual effort at work).

Thus it is clear that motivation is always related to the needs, desires, and encouragement, as well as being the cause of an employee trying to achieve certain goals, and behave to maintain and control the activities that must be carried out in an organization. In 
addition, it can be concluded that work motivation is:

1. As a condition that moves people towards a certain goal.

2. An expertise in directing employees and companies to work successfully, so that employee desires and company goals are achieved.

3. As an initiation and direction of behavior. Motivational lessons are actually behavioral lessons.

4. As energy to generate impulse within.

5. As a condition that influences arousing, directing, and maintaining behavior related to the work environment.

\subsection{Conceptual Framework}

According to Uma Sekaran in Sugiyono (2016: 60) states that the framework of thinking is a conceptual model of how theories relate to various factors that have been identified as important problems. Thinking framework in a study needs to be stated if in the study regarding two or more variables. If the research only discusses a variable or more independently, then what the researcher does besides presenting a theoretical description for each variable, is also an argument against variations in the magnitude of the variable under study (Sapto Haryoko, 1999, in Sugiyono, 2010). Work environment and motivation are elements of human resource management that have an influence on employee productivity. Based on the description of the theories that have been put forward as well as existing problems, it is necessary to make a research framework. The aim is to provide convenience in reviewing the conditions under study. The framework for this research can be seen in the following figure:

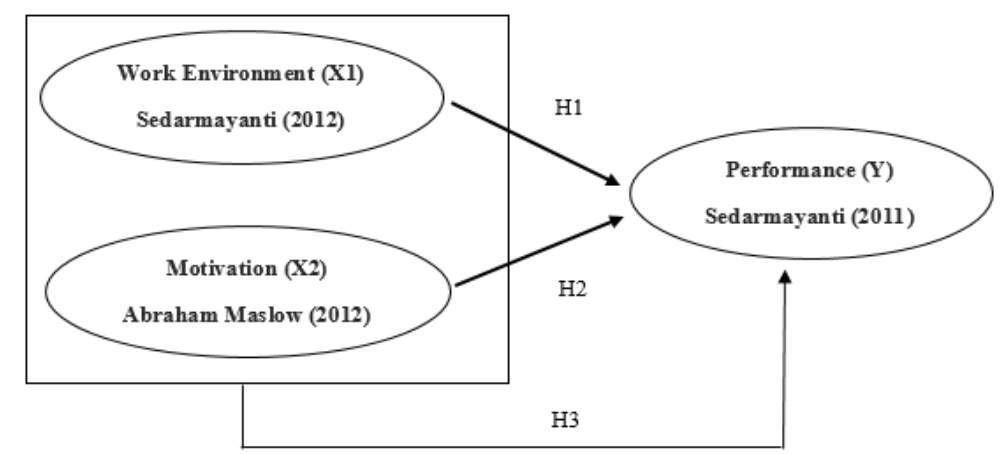

Fig.1. Research Framework

\section{Research Methods Of Study}

In relation to this research the hypothesis is a temporary answer to a problem at hand and is the starting point of a discussion. Associative hypothesis, is a temporary answer to the associative problem, which is about asking the relationship / influence between two or more variables. In accordance with the aims and objectives of this study, they want to prove the 
effect of the independent variables on the dependent variable.

This study uses a quantitative-correlative method with a case study approach that is supported by surveys and correlation analysis techniques, namely the study of the relationship of two or more variables in a situation or group of subjects. Correlation research is used to get a systematic, factual and accurate picture of the facts and performance of employees at PT, $\mathrm{XYZ}$ as the population as they are, also linking work environment variables, and motivation with other variables namely performance, as well as testing hypotheses and developing generalizations according to the principles a principle that has universal validity.

This research was designed as an ex post facto research, which means after the incident. The researcher investigates the problem by studying the related variables and the main problem of the researcher in this study is immediately observed subsequently to find the causes that cause these effects.

Based on the research title: The effect of the work environment and motivation on employee performance at PT. XYZ, it was determined that this study consisted of two variables, namely:

1. Independent variable (free), this variable is often referred to as a stimulus variable, predictor, antecedent. Which affects or is the cause of the change or the emergence of the dependent variable (Sugiyono, 2016: 39). This variable is in the form of work environment, motivation, work discipline which is a factor of $\mathrm{X}$.

2. Dependent Variables (related) that is often referred to as output variables, criteria, consequent / bound. Dependent variable is a variable that is affected or which becomes a result, because the independent variable (Sugiyono, 2016: 39). This variable is in the form of performance as a $\mathrm{Y}$ factor.

Population is a generalization area that consists of objects / subjects that have certain qualities and characteristics determined by researchers to be studied and then drawn conclusions (Sugiyono, 2016: 215), said that the population is concerned with data, not people or objects, then the population is the totality of all possible values, both counting and quantitative and qualitative measurements, rather than certain characteristics regarding a complete set of objects. So the population is an object / subject that is in an area and meets certain conditions that are related to the problem and meet certain conditions that are related to the problem under study. The population referred to by researchers in this study were employees of the Welding Section of PT. XYZ as many as 70 people.

The sampling technique used is non-probability sampling, which is a sampling technique that does not provide equal opportunities for each element (member) of the population to be selected in sampling (Masyhudzulhak, 2015: 43). Next the existing population was sampled using the saturation / census sampling method in Masyhudzulhak (2015: 43) explained that this technique is a way of collecting data if the population is relatively small. Thus the number of samples of this study were 70 people.

The data used in this study are primary data and secondary data. Primary data is data obtained directly from research subjects / respondents contained in the questionnaire, with respondents being Welding Section employees of PT. XYZ numbered 70 people. The questionnaire submitted to the respondent is a reference to get relevant information about the research subject.

Secondary data is data obtained through other parties indirectly obtained by researchers from research subjects. Secondary data sources obtained by examining documents related to the object of research include production data.

Data collection procedures and techniques used in this study are: 
1. Field research (Survey), a questionnaire is a data collection technique by giving a set of questions or written statements to respondents to be answered (Sugiyono, 2016). Questionnaires can be closed / open questions / statements, can be given directly to respondents. The instrument used was to provide a questionnaire (questionnaire), distributed to the section welding unit employees who were the object of research.

2. Observation, namely by making direct observations on subjects that are the target of research. Through this technique the authors hope will be able to understand the objective conditions of various things that are assumed to be related factors that become secondary data to support the technical discussion of research results.

3. Literature study, carried out by reading, gathering and studying various sources of information which includes sources of literature and relevant references in the form of journals, previous final work research and literature books related to the research topic.

In this study, data were processed using statistical methods through SPSS for Windows. Data analysis method used in this study consisted of three stages, namely stages in the form of research tests, stages of research regression analysis and stages of correlation between dimensions.

\section{Results and Discussion}

\subsection{Simultaneous Testing Results (Test F)}

Simultaneous Test to find out whether there is an influence of the Work Environment (X1) and Motivation (X2) on the dependent variable (Performance), namely Performance (Y) in PT. $\mathrm{XYZ}$

\begin{tabular}{ccccccc}
\hline \multicolumn{7}{c}{ Table 3. Simultant F Test } \\
\hline Model & & \multicolumn{5}{c}{ ANOVA $^{\mathbf{a}}$} \\
\hline 1 & Regression of Squares & df & Mean Square & F & Sig. \\
\hline & Residual & 3.180 & 3 & 4.727 & 98.793 & $.000^{\mathrm{b}}$ \\
& Total & 17.338 & 69 & .048 & & \\
\hline
\end{tabular}

\footnotetext{
a. Dependent Variable: $\mathrm{Y}$

b. Predictors: (Constant),X2, X1

Source: Primary Data (2017)
}

Significantly significant test results can be seen in Table 3, the F Test was conducted to determine the effect of the variable Work Environment, and Motivation on Employee Performance at PT. XYZ simultaneously. Sig. Value of 0.000 indicates a significance level of alpha of 0.05 two tailed definitively significant. Meanwhile, for testing with the $F$ test is to compare the values of $F$ table with F count. Fcount value of 98.793, Ftable is 2.75 (see Table F), thus the result of Fcount $>$ Ftable $(98.793>2.75)$ then Ho is rejected and Ha is accepted. It can be concluded that the Work Environment, and Motivation variables affect the performance of employees at PT. XYZ

\subsection{Partial Testing Results (T Test)}

$\mathrm{T}$ test was conducted to determine the effect of Work Environment (X1), and Motivation (X2) variables on performance partially (individually). $\mathrm{T}$ test is done by comparing the calculated $t$ value with $t$ table. If $t$ arithmetic $>t$ table, it is said that the effect is significant, and if $t$ count $<t$ table, it is said that the effect is not significant. 
Table 4. Parsial T Test

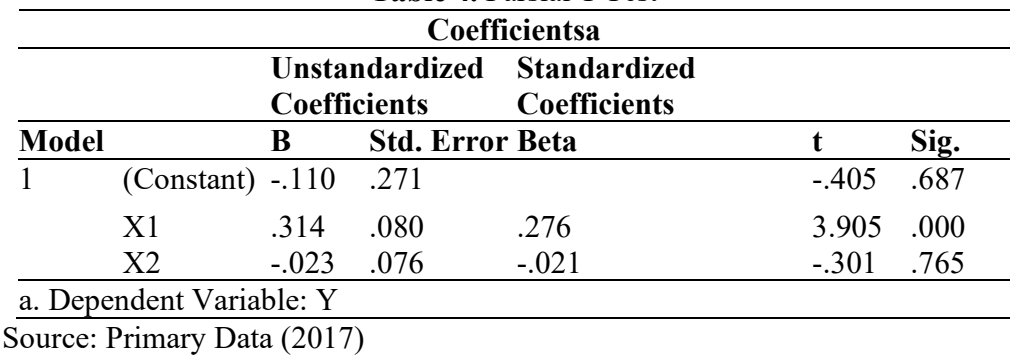

\subsection{Partial Hypothesis Test for Work Environment variables}

Ho: The work environment has no effect on employee performance at PT. XYZ Ha: Work environment influences employee performance at PT. XYZ. In Table 4 the Sig. for the Work Environment variable (X1) it can be seen that the Significance value is 0,000 because values below 0.05 can be said to be significant. Tests using the $t$ test are, the value of $t$ table on alpha (two tail) $\mathrm{df}=\mathrm{n}-4=70-4=66$ is 1,99 , while the calculated t value in table 5.16 above is equal to the $\mathrm{t}$ test $=3$, 905. means $\mathrm{t}$ arithmetic $>\mathrm{t}$ table then Ho is rejected and $\mathrm{Ha}$ is accepted, thus indicating the Work Environment has a significant effect on performance.

\subsection{Partial Hypothesis Test for Motivation variables}

Ho: Motivation has no effect on employee performance at PT. XYZ. Ha: Motivation affects the performance of employees of PT. XYZ. In Table 4 the Sig. for the Motivation variable the Significance value of 0.765 is seen because the value is above 0.05 then it can be said to be insignificant. Tests using the $t$ test is, the value of $t$ table on alpha (two tail) $d f=n-4$ $=70-4=66$ is 1.99 , while the $\mathrm{t}$ value in the table 5.20 above is equal to the $t$ test $=-0.301$ means $t$ count $<$ table then Ho is accepted and Ha is rejected, thus showing Motivation has no significant effect on performance.

\subsection{Coefficient of Determination (R2)}

The coefficient of determination (R2) is essentially to measure the ability of the model to explain the dependent variable. A value of $R$ ( $R$ Square) close to one means that the independent variable provides almost all the information needed to predict the dependent variables. In connection with this, the results of the calculation of the coefficient of determination in Table 5 follows:

Table 5. Coefficient of Determination Model Summary

\begin{tabular}{llll}
\multicolumn{4}{c}{ Model Summary $^{\mathbf{b}}$} \\
\hline Model $\quad$ R & R Square & Adjusted R Square & Std. Error of the Estimate \\
\hline $1 \quad .904^{\mathrm{a}} \quad .818$ & .810 & .218734 \\
\hline a. Predictors: (Constant), X2, X1 & & \\
\hline b. Dependent Variable: Y & & \\
Source: Primary Data (2017) &
\end{tabular}


Based on table 5 above, it can be said that the magnitude of $\mathrm{R}$ or the correlation of the magnitude of the independent variables Work Environment (X1), and Motivation (X2) together against the dependent variable Performance $(\mathrm{Y})$ is equal to 0.904 . R Square or the determinant coefficient of 0.818 or $81,8 \%$, shows that the performance is influenced by the three independent variables used in this study (ie independent Work Environment (X1), and Motivation (X2) by $81.8 \%$, and there are still influences from other factors which is equal to $18.2 \%$.

\section{Conclusion}

Based on the research conducted above, it shows that there are limitations that occur in this study. Therefore, suggestions for further research are:

a. It is hoped that for further research, researchers can use larger samples to produce stronger research.

b. For further research it is recommended to examine other factors besides the work environment, and motivation that can have a significant influence on employee performance such as competence, organizational culture, workload, and other factors associated with improving employee performance.

\section{References}

[1] Alex, S Nitisemito, 2008, Manajemen Personalia, Ghalia Indonesia, Jakarta.

[2] Anwar Prabu Mangkunegara, 2010, Manajemen Sumber Daya Manusia Perusahaan, Remaja Rosdakarya, Bandung. Anita, Julia, Nasir Aziz, Mukhlis dan Yunus. 2013. "Pengaruh Penempatan dan Beban Kerja Terhadap Motivasi Kerja dan Dampaknya pada Prestasi Kerja Pegawai Dinas Tenaga Kerja dan Mobilitas Penduduk Aceh. Jurnal Manajemen Pascasarjana, Unsyiah. Volume 2 Nomor 1.

[3] Arianto, Dwi Agung Nugroho. 2013. "Pengaruh Kedisiplinan, Lingkungan Kerja, dan Budaya Kerja Terhadap Kinerja Tenaga Pengajar”. Journal Economia. Volume 9

[4] Bernardin, H.John and Russel. 2010.Human Resource Nomor 2.

[5] Bejo Siswanto. 2010. Manajemen Tenaga Kerja Rancangan dalam Pendayagunaan dan Pengembangan Unsur Tenaga Kerja. Bandung : Sinar Baru.

Management.New York: McGraw Hill

[6] Cho, Yoon Jik and James L. Perry. 2011. "Intrinsic Motivation and Employee Attitudes: Role of Managerial Trustworthiness Goal Directedness, and Extrinsic Reward Expectancy". Review of Public Personnel Administration. XX(X) 1-25.

[7] Cole, Nina. 2008. "Consistency in Employee Discipline: an empirical exploration". Personal Review. Volume 37 Nomor 1.

[8] Colquitt, LePine, \& Wesson. (2015). Organizational Behavior: Improving Performance and Commitment in the Workplace, Fourth Edition. New york: Mc Graw Hill Education.

[9] Davis, Keith. Newstrom, John. (2008). Perilaku Dalam Organisasi.Jakarta: Erlangga Dessler, Gary, 2010. Manajemen Sumber Daya Manusia, Jakarta: PT. Indeks

[10] Ferry Moulana, Bambang Swasto Sunuharyo, dan Hamidah Nayati Utami.2017. "Pengaruh Lingkungan Kerja Terhadap Kinerja Karyawan Melalui Variabel Mediator Motivasi Kerja (Studi pada Karyawan PT. Telkom Indonesia,Tbk Witel Jatim Selatan, Jalan A. Yani, Malang)”. Jurnal Administrasi Bisnis (JAB).Vol. 44 No.1

[11] Gouzali Saydam, 2008, Manajemen Sumber Daya Manusia Jilid I, Gunung Agung, Jakarta. 
Harlie, M. 2012. Pengaruh Disiplin Kerja, Motivasi dan Pengembangan Karier terhadap Kinerja PNS pada Pemerintahan Kab. Tabalong. Jurnal Aplikasi Manajemen. Volume 10 Nomor 4.

[12] Hasibuan, Malayu S.P. 2009. Manajemen Dasar, Pengertian, Dan Masalah. Jakarta: PT Bumi Aksara.

[13] Hon, Alice H. Y. and Wilco W. Chan. 2013. "The Effects of Group Conflict and Work Stress on Employee Performance”. Cornell Hospitality Quarterly. 54(2) 174-184.

[14] Husein, Umar. 2008. Riset Sumbar Daya Manusia Manusia Dalam Organisasi. PT. Gramedia Pustaka Utama. Jakarta.

[15] Jeffrey M. Bale, Julie A. Gazmararian dan Lisa Elon. 2015.” Effect of the Work Environment on Using Time at Work to Exercise". American Journal of Health Promotion. Volume 29 Nomor 6.

[16] Juan, Antonio Moreno, et al. 2008. "Motivation, Discipline Behaviour, equal treatment and dispotional Flow in Physical Education". the journal of international social research. Volume I/4.

[17] Kasmir. 2016. Manajemen Sumber Daya Manusia ( Teori dan Praktik).PT. Raja Grafindo Persada. Jakarta.

[18] Keijzer, B. 2010. "Employee Motivation and Performance, bachelor Bussiness Studies". Tesis Royal Melbourne Institute of Technology.

[19] Khairani Sofyan, Diana. 2013. "Pengaruh Lingkungan Kerja Terhadap Kinerja Kerja Pegawai BAPPEDA”. Malikussaleh Industrial Engineering Journal. Vol.2 No.1 (18-23).

[20] Kreitner, Robert dan Kinicki. 2008. Organizational Behavior. 8th Edition. Boston:McGraw Hill.

[21] Kumari, Neeraj. 2014. "Using Performance Appraisal as an Effective Tool for Motivating the Employees Performance: A Live Study". Business and Perspectires Research. January- July.

[22] Kumar Pradhan, Rabindra and Lalatendu Kesari Jena1. 2017. "Employee Performance at Workplace: Conceptual Model and Empirical Validation”. Business Perspectives and Research.5(1) 69-85.

[23] Luthans, Fred. 2011. Organizational Behavior: An Evidence Based approach.New York: The McGrow - Hill Companies, Inc.

[24] L. Mathis, Robert - H. Jackson, John., 2011. Human Resource Management (edisi10).Jakarta : Salemba Empat

[25] Mark A. Covaleski et al. 2008. "The calculated and the Avowed: Techniques of discipline and A Struggles Over Identity in Big Six Public Accounting Firm”.Sage Journal. Volume 43 Nomor 2.

[26] Mondy dan Noe. 2010. Human Resource Management, PT Bumi Aksara, Jakarta

[27] Nebel, E. C III. 2015. "Motivation, Leadership, and Employee Performance: A Review". The Cornell H.R.A Quarterly. 7 Juni.

[28] Nicholas Odoyo Simba et al. 2016. "Impact of Discipline on Academic Performance of Pupils in Public Primary Schools in Muhoroni Sub-Country, Kenya". Journal of Education and Practice. Volume 7 Nomor 6.

[29] Novita Hidayat, Cynthia. 2015. "Pengaruh Lingkungan Kerja Dan Motivasi Kerja Terhadap Kinerja Karyawan Kantor PT. Keramik Diamond Industries.”. AGORA.Vol. 3, No. 2.

[30] Nurlaila, 2010. Manajemen Sumber Daya Manusia I. Ternate: Penerbit LepKhair

[31] Obule, Victor. 2012. "Influence of staff discipline and attitude to work on job satisfaction lectures in tertiary institutions in cross river state". Public Policy and Administration research. Volume 2 Nomor 3.

[32] Prihantoro, Agung. 2012. “Peningkatan Kinerja Sumber Daya Manusia Melalui Motivasi, Disiplin, Lingkungan Kerja dan Komitmen”. Value Added. Volume 8 Nomor. 2.

[33] Robbins, Stephen P \& Judge, Timothy A. 2013. Organizational Behavior Edition 15. New Jersey: Pearson Education

[34] Schermerhorn, J. R., Hunt, J. G., Osborn, R. N., dan Uhl-Bien, M. (2010). Organizational Behavior 11th Edition. New Jersey: John Wiley \& Sons, Inc.

[34] Sedarmayanti. (2011). Manajemen Sumber Daya Manusia, Reformasi Birokrasi dan Manajemen Pegawai Negeri Sipil (cetakan kelima). Bandung : PT Refika Aditama

[35] Shoraj, Dhritan and Shyqyri Llaci. 2015. "Motivation and Its Impact on Organizational Effectiveness in Albanian Businesses". SAGE Open. 1-8. 
[36] Sondang P, Siagian. 2008. Manajemen Sumber Daya Manusia. Jakarta: Bumi Aksara. 